\title{
Perbedaan kadar caffeic acid phenethyl ester pada propolis ekstrak etanol dan propolis ekstrak air
}

\author{
The difference of caffeic acid phenethyl ester level in ethanol extract propolis and water extract \\ propolis
}

\author{
RIANI DWI HASTUTI, DIDING PRASETYO, SRI HARTATI HADINOTO \\ Fakultas Kedokteran, Universitas Sebelas Maret. Jl. Ir. Sutami 36A Surakarta 57126, Jawa Tengah
}

Manuskrip diterima: xxxxx. Revisi disetujui: 26 Juli 2012.

\begin{abstract}
Hastuti RD, Prasetyo D, Hadinoto SH. 2013. The difference of caffeic acid phenethyl ester level in ethanol extract propolis and water extract propolis. Biofarmasi 11: 43-47. Propolis is a natural product derived from plant resin collected by honeybeen and its composition has wide range of biological activity. CAPE is the ester of caffeic acid, a derivative of phenolic acid, a flavonoid-like compound, one of the major components of propolis. CAPE is reported can protect nephrotoxicity due to cisplatin induction, inhibiting the growth of various types of abnormal cells, having an anti-inflammation activity, antioxidant activity, cyclooxygenase activity, vasodilatation activity in rat aorta, potential inhibitor of nitric oxidant, inhibitor oxidative process, and effectively suppress the growth of cataract in rat. Propolis can not be used as raw material, and it must be purified by extraction with solvent. Different solvents may extract different compounds, influencing its activity. The purpose of this research was to determine the difference levels of CAPE in ethanol extract propolis and water extract propolis. This research was a pure experimental research using the post-test only design. The sample of this research was raw propolis taken from bees farming in Gejen RT. 03 RW. 02, Kerjo, Karanganyar. Sampling was performed by a purposive sampling. Sample was extracted with a maserasion method with the solvents of ethanol and water. In each extract propolis was made five samples. The determination of the level of CAPE on propolis was performed by using UV-Vis spectrophotometry with Prussian Blue method. The data of the level of CAPE was analyzed by the statistical test of independent $t$-test. The results showed that the average of CAPE level in ethanol extract propolis was $12.268 \pm 0.658 \mu \mathrm{g} / \mathrm{mL}$ and the average of CAPE level in water extract propolis was $5.564 \pm 0.332 \mu \mathrm{g} / \mathrm{mL}$, with $p=0.125(\mathrm{p}>0.05)$. There was no significant difference between extract ethanol propolis and water extract propolis.
\end{abstract}

Keywords: CAPE, propolis, Prussian blue method, UV-Vis spectrophotometry

\section{PENDAHULUAN}

Propolis adalah produk alami yang berasal dari resin tumbuhan yang dikumpulkan oleh lebah madu. Propolis telah secara luas digunakan dalam pengobatan tradisional dan terbukti memiliki berbagai aktivitas biologi, antara lain antimikrobial, antiprotozoal, antiparasit, antiinflamasi, antiagen penyebab ulserasi, antitumor, antioksidatif, antiviral, dan hepatoprotektif. Selain untuk pengobatan tradisional, baru-baru ini propolis populer dimanfaatkan sebagai suplemen makanan di banyak negara dan dipercaya dapat meningkatkan kesehatan dan mencegah penyakit (Bankova et al. 2000; Banksnota et al. 2001; Lotfy 2006; Marcucci 1995).

Komposisi propolis terutama tergantung pada keberadaan tumbuh-tumbuhan di daerah mana propolis dikumpulkan, waktu dikumpulkan, dan secara sekunder tergantung pada jenis pelarut yang digunakan untuk ekstraksi (Bankova et al. 2000; Mishima 2005). Akibatnya, terdapat lebih dari 160 senyawa yang diidentifikasi dalam propolis, diantaranya senyawa aromatik, prenylated $p$ coumaric acid, derivat acetophenone, caffeoylquinic acid, lignan, diterpenic acid, triterpene, monoterpene, sesquiterpene, gula, serta asam fenolik dan flavonoid sebagai komponen utama (Bankova et al. 1998).

Cuppett dalam Widjaja (2008) menyatakan bahwa caffeic acid phenethyl ester (CAPE) adalah ester asam caffeic, turunan asam fenolik. CAPE memiliki struktur mirip flavonoid dan merupakan salah satu komponen utama pada propolis. CAPE dilaporkan dapat melindungi nefrotoksisitas akibat induksi cisplatin (Ozen et al. 2004) dan menghambat pertumbuhan berbagai jenis sel yang abnormal (Khayyal et al. 1993). Selain itu, CAPE juga memiliki sifat antiinflamasi (Marquez et al. 2004), aktivitas antioksidan, aktivitas siklooksigenase (Rossi et al. 2002), dan aktivitas vasodilatasi pada aorta tikus (Cicala et al. 2003). Beberapa penelitian menunjukkan bahwa CAPE terbukti berperan sebagai inhibitor potensial nitrit oksida (Nagaoka et al. 2003), inhibitor proses oksidatif (Frenkel et al. 1993), dan efektif menekan pertumbuhan katarak pada tikus.

Propolis tidak dapat digunakan sebagai bahan mentah dan harus dimurnikan melalui ekstraksi menggunakan pelarut (Pietta et al. 2002). Cunha dalam Sforcin (2011) menyatakan bahwa ekstraksi dengan menggunakan pelarut yang berbeda akan menghasilkan komponen yang berbeda serta mempengaruhi aktivitasnya. Propolis biasanya 
diekstrak dengan menggunakan air dan etanol pada berbagai konsentrasi sebagai pelarut. Isosakuranetin, kuersetin, dan kaempferol kebanyakan diekstrak dari campuran propolis dengan etanol 60\%. Etanol 70\% umumnya digunakan untuk mengekstrak pinocembrin dan sakuranetin. Etanol 80\% digunakan untuk mengekstrak kaempferide, acacetin, dan isorhamnetin dari propolis. Propolis yang diekstrak dengan etanol 60-80\% sangat menghambat pertumbuhan mikroba dan yang diekstrak dengan etanol 70-80\% mempunyai aktivitas antioksidan terbesar. Adapun 80\% ekstrak etanol propolis sangat menghambat aktivitas enzim hyaluronidase (Park dan 1998). Sementara itu, propolis ekstrak air dapat menghambat pertumbuhan lini sel yaitu McCoy, HeLa, SP2/0, HEp-2, dan BHK21 serta menstimulasi pertumbuhan sel normal yaitu limfosit, ginjal, hati, dan limpa tikus (Najafi et al. 2007). Konsentrasi tertinggi senyawa fenolik diperoleh dengan menggunakan pelarut etanol pada konsentrasi yang lebih rendah dan konsentrasi propolis mentah yang lebih tinggi (Cottica et al. 2011).

Meskipun etanol merupakan pelarut yang paling umum digunakan, propolis ekstrak etanol memiliki beberapa kelemahan, seperti memiliki bau yang kuat, rasa yang tidak enak, dan konsentrasi etanol yang tinggi (Ghisalberti 1979; Burdock 1998), sehingga studi tentang propolis ekstrak air terus meningkat. Propolis ekstrak air memiliki aktivitas antioksidan yang baik terkait dengan tingginya kandungan senyawa fenolik. Di sisi lain, Demestre et al. (2008) melaporkan bahwa CAPE memiliki kelarutan yang rendah terhadap air, namun dapat dibuat lebih larut dengan penambahan lemak.

Tujuan penelitian ini adalah untuk mengetahui perbedaan kadar CAPE pada propolis ekstrak etanol dan propolis ekstrak air.

\section{BAHAN DAN METODE}

\section{Waktu dan tempat penelitian}

Penelitian ini dilakukan di Laboratorium Biokimia, Fakultas Kedokteran, Universitas Sebelas Maret, Surakarta.

\section{Alat dan bahan}

Alat yang dibutuhkan dalam penelitian ini yaitu labu takar $10 \mathrm{ml}, 100 \mathrm{ml}$, dan $250 \mathrm{ml}$, erlenmeyer tutup $100 \mathrm{ml}$ dan $250 \mathrm{ml}$, gelas beker $250 \mathrm{ml}$, pipet tetes, mikropipet 0$10 \mu \mathrm{l}, 10-100 \mu \mathrm{l}$, dan 100-1000 $\mu \mathrm{l}$, botol timbang, spektrofotometer, kertas saring, kain lap, sabun cuci, dan sikat tabung.

Sementara itu, bahan yang dibutuhkan meliputi CAPE $\left(1 \times 10^{-3}\right.$ sampai dengan $\left.2,98 \times 10^{-3} \mathrm{M}\right)$, asam asetat, etanol $80 \%$, aquabidest, $\mathrm{HCl} 0,1 \mathrm{M}, \mathrm{K}_{3} \mathrm{Fe}(\mathrm{CN})_{6}$ 0,0008 M/0,1 M $\mathrm{HCl}, \mathrm{FeCl}_{3}$ 0,1 M/0,1 M HCl, dan propolis mentah.

\section{Jenis penelitian}

Penelitian ini merupakan penelitian eksperimental murni.

\section{Subjek penelitian}

Subjek dari penelitian ini berupa propolis mentah yang diperoleh dari peternakan lebah di daerah Gejen RT 03 RW 02 Kerjo, Karanganyar.

\section{Teknik sampling}

Teknik sampling yang dilakukan adalah purposive sampling. Pemilihan subjek penelitian didasarkan atas sifat-sifat tertentu yang berkaitan dengan karakteristik populasi. Karakteristik populasi harus sudah diketahui terlebih dahulu dari penelitian-penelitian sebelumnya (Taufiqqurohman 2009).

\section{Cara kerja \\ Tahap persiapan}

Pembuatan propolis ekstrak etanol dan propolis ekstrak air dilakukan di Laboratorium Biokimia, Fakultas Kedokteran, Universitas Sebelas Maret, Surakarta. Propolis dibuat berdasarkan metode Gonzalez (2003) yang telah dimodifikasi. Ekstrak dibuat dengan mengambil 0,1 g propolis kering dan ditambah dengan $30 \mathrm{ml}$ air. Kemudian ekstrak dimaserasi selama 12 jam, selanjutnya sampel dimasukkan ke dalam shaker dan disentrifugasi dengan kecepatan $50 \mathrm{rpm}$ selama 30 menit pada suhu $30^{\circ} \mathrm{C}$. Supernatan yang didapat kemudian difiltrasi 5 jam kemudian. Prosedur yang sama kemudian diulang sebanyak 5 kali. Modifikasi yang dilakukan adalah dengan memperpanjang lama perendaman menjadi 24 jam dan tidak menggunakan shaker pada proses pengadukan.

\section{Tahap pelaksanaan percobaan dan pengukuran hasil}

Pengukuran kadar CAPE propolis ekstrak etanol dan propolis ekstrak air dilakukan di Laboratorium Biokimia, Fakultas Kedokteran, Universitas Sebelas Maret, Surakarta dengan menggunakan spektrofotometer menurut metode Prussian blue yang dilakukan dengan langkah-langkah sebagai berikut. Standar CAPE $(284,31 \mathrm{~g} / \mathrm{mol})$ ditentukan dengan membagi CAPE standar menjadi enam kelompok ukuran yaitu 0, 4, 8, 12, 16, dan $20 \mu \mathrm{l}$. Masing-masing kelompok ukuran CAPE standar ditambahkan $400 \mu \mathrm{l} \mathrm{K} \mathrm{K}_{3} \mathrm{Fe}$ $(\mathrm{CN})_{6}$ 0,0008 M/0,1 M HCl dan $400 \mu \mathrm{FeCl}_{3}$ 0,1 M/0,1 M $\mathrm{HCl}$, setelah itu dikocok dan ditunggu selama 7 menit kemudian diamati absorbansi warna pada spektofotometer dengan panjang gelombang $700 \mathrm{~nm}$. Nilai absorbansi dicatat kemudian data diubah ke dalam bentuk grafik CAPE standar, dimana sumbu $\mathrm{x}$ menunjukkan nilai CAPE standar dan sumbu y menunjukkan nilai absorbansi. Sampel propolis dibagi menjadi dua kelompok yaitu propolis ekstrak etanol dan propolis ekstrak air. Masingmasing propolis diambil sebanyak $10 \mu \mathrm{l}$ kemudian diencerkan dengan etanol $80 \%$, setelah itu ditambahkan dengan $400 \mu \mathrm{l} \mathrm{K}_{3} \mathrm{Fe}(\mathrm{CN})_{6} 0,0008 \mathrm{M} / 0,1 \mathrm{M} \mathrm{HCl}$ dan $400 \mu \mathrm{l}$ $\mathrm{FeCl}_{3}$ 0,1 M/0,1 M HCl hinga volumenya menjadi $10 \mathrm{ml}$ lalu dikocok dan ditunggu selama 7 menit, kemudian diamati absorbansi warna pada spektrofotometer dengan panjang gelombang $700 \mathrm{~nm}$. Nilai absorbansi dicatat kemudian data dipindahkan ke dalam bentuk grafik CAPE standar untuk menentukan nilai CAPE yang terdapat dalam sampel propolis. Tahap-tahap pengukuran nilai absorbansi tersebut kemudian diulang sebanyak tiga kali untuk tiap 
sampel propolis. Nilai rata-rata kadar CAPE dari tiap sampel propolis dihitung kemudian dibandingkan kadar CAPE antara propolis ekstrak etanol dan propolis ekstrak air.

\section{Analisis data}

Data hasil penelitian dianalisis dengan uji-t tidak berpasangan dengan menggunakan program SPSS 17.0 for Windows untuk mengetahui ada tidaknya perbedaan rerata kadar CAPE antara propolis ekstrak etanol dan propolis ekstrak air (Dahlan 2007).

\section{HASIL DAN PEMBAHASAN}

Pada penentuan kadar CAPE pada sampel digunakan CAPE standar dalam pelarut etanol $80 \%$ dengan konsentrasi 0 ; 2,5; 5; 7,5; 10; dan 12,5 $\mu \mathrm{g} / \mathrm{mL}$ dan dalam pelarut air dengan konsentrasi $0 ; 2,5 ; 5 ; 10 ; 20$; dan 30 $\mu \mathrm{g} / \mathrm{mL}$. Pada saat CAPE standar direaksikan dengan reagen Prussian blue dihasilkan larutan berwarna hijau. Semakin tinggi konsentrasi CAPE standar maka warna larutan yang dihasilkan semakin pekat. Hal ini menunjukkan bahwa CAPE standar memiliki kemampuan mereduksi.

CAPE standar yang telah direaksikan dengan reagen Prussian blue kemudian diamati nilai absorbansinya dengan menggunakan spektrofotometer UV-Vis pada panjang gelombang $700 \mathrm{~nm}$. Ketika direaksikan dengan reagen Prussian blue, warna yang dihasilkan adalah warna hijau. Warna yang dihasilkan oleh seluruh sampel terlalu pekat, sehingga perlu dilakukan pengenceran agar dapat dibaca absorbansinya dengan spektrofotometer UV-Vis. Hasil pengukuran absorbansi larutan CAPE standar menggunakan pelarut etanol 80\% disajikan pada Tabel 1 .

Berdasarkan hasil pengukuran CAPE standar, selanjutnya dibuat kurva kalibrasi antara absorbansi (A) dan konsentrasi propolis (C). Pembuatan kurva kalibrasi tersebut bertujuan untuk membantu menentukan kadar CAPE yang terdapat dalam sampel propolis ekstrak etanol dan propolis ekstrak air dengan menggunakan persamaan regresi dari kurva kalibrasi. Adapun hasil pengukuran absorbansi larutan CAPE standar menggunakan pelarut air dapat dilihat pada Tabel 1 .

Gambar 1 dan 2 memperlihatkan bahwa nilai absorbansi berbanding lurus dengan konsentrasi propolis yang mengikuti persamaan regresi linier. Dari pengukuran kadar CAPE standar dengan pelarut etanol didapatkan kurva kalibrasi dengan persamaan regresi $\mathrm{y}=0,0194 \mathrm{x}$ 0,0073 dan harga koefisien korelasi (r) sebesar 0,996. Adapun dari hasil pengukuran kadar CAPE standar dengan pelarut air didapatkan kurva kalibrasi dengan persamaan regresi $\mathrm{y}=0,0132 \mathrm{x}-0,0013$ dan harga koefisien korelasi (r) sebesar 0,9987. Nilai (r) yang mendekati 1 membuktikan bahwa persamaan regresi tersebut bersifat linier. Persamaan ini digunakan sebagai standar untuk pengukuran kadar CAPE pada propolis ekstrak etanol dan propolis ekstrak air.

Berdasarkan persamaan regresi yang didapat dari pengukuran nilai absorbansi CAPE standar pada pelarut etanol $80 \%$ maka dapat ditentukan konsentrasi CAPE pada
Tabel 2. Adapun pada konsentrasi CAPE dengan pelarut air didapatkan hasil seperti yang disajikan pada Tabel 2 . Perbandingan konsentrasi CAPE pada propolis ekstrak etanol dan propolis ekstrak air disajikan pada Tabel 3.

Konsentrasi rata-rata CAPE pada propolis ekstrak etanol berdasarkan data yang diperoleh adalah sebesar $12,268 \mu \mathrm{g} / \mathrm{mL}$ dan konsentrasi rata-rata CAPE pada propolis ekstrak air sebesar 5,564 $\mu \mathrm{g} / \mathrm{mL}$. Dari hasil tersebut terlihat bahwa konsentrasi CAPE pada propolis ekstrak etanol lebih tinggi daripada propolis ekstrak air. Selanjutnya, data tersebut diuji menggunakan uji-t tidak berpasangan untuk mengetahui ada tidaknya perbedaan rerata konsentrasi CAPE yang singnifikan antara dua kelompok data.

Tahapan pertama dalam analisis data penelitian yaitu dilakukan uji normalitas pada data yang diperoleh untuk mengetahui sebarannya normal atau tidak. Sebaran data yang normal merupakan syarat mutlak dilakukan uji-t tidak berpasangan. Normalitas sebaran data dapat diketahui dengan menggunakan uji Shapiro-Wilk karena jumlah sampel kurang dari 50. Pada uji normalitas Shapiro-Wilk didapatkan nilai $\mathrm{p}=0,481$ untuk ekstrak etanol dan $\mathrm{p}=0,101$ untuk ekstrak air. Oleh karena nilai $\mathrm{p}>0,05$ maka dapat disimpulkan bahwa distribusi atau sebaran data bersifat normal. Oleh karena syarat distribusi atau sebaran data terpenuhi maka uji hipotesis yang dipakai adalah uji-t tidak berpasangan.

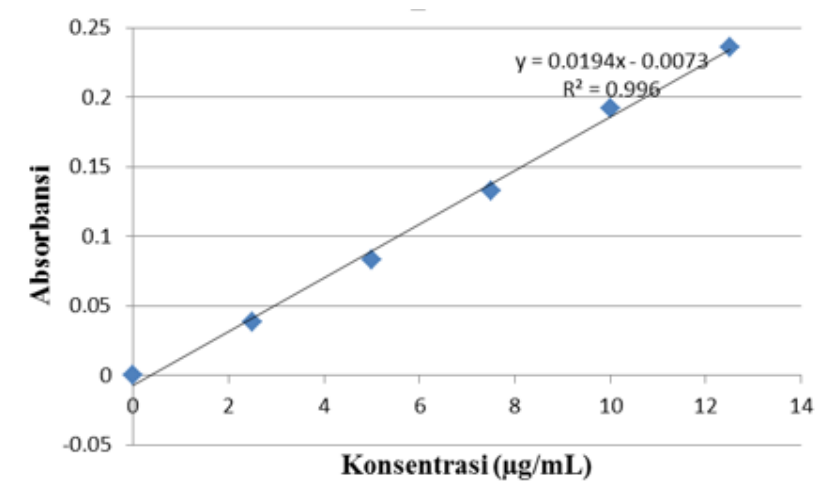

Gambar 1. Kurva kalibrasi CAPE standar dengan pelarut etanol $80 \%$.

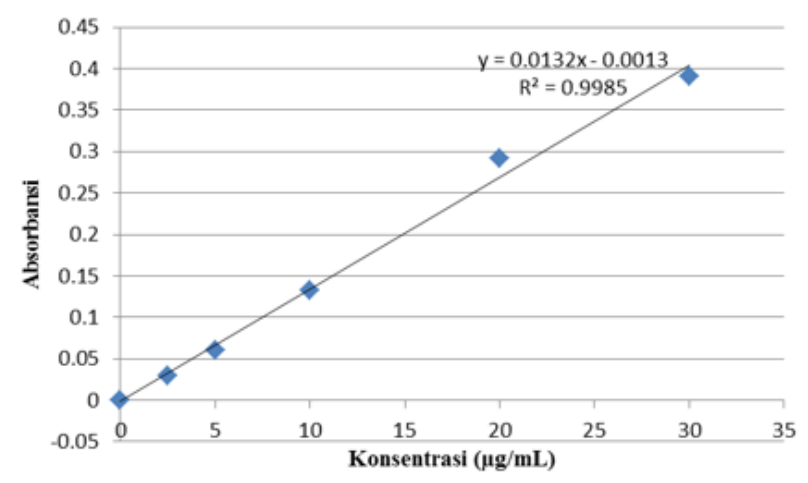

Gambar 2. Kurva kalibrasi CAPE standar dengan pelarut air. 
Tabel 1. Nilai absorbansi CAPE standar dengan pelarut etanol $80 \%$ dan pelarut air

\begin{tabular}{ccc}
\hline \multirow{2}{*}{ Konsentrasi $(\boldsymbol{\mu g} / \mathbf{m L})$} & \multicolumn{2}{c}{ Absorbansi (A) } \\
\cline { 2 - 3 } & Pelarut etanol & Pelarut air \\
\hline 12,5 & 0,390 & 0,236 \\
10,0 & 0,291 & 0,192 \\
7,5 & 0,133 & 0,133 \\
5,0 & 0,060 & 0,083 \\
2,5 & 0,029 & 0,038 \\
0,0 & 0,000 & 0,000 \\
\hline
\end{tabular}

Tabel 2. Konsentrasi CAPE pada propolis ekstrak etanol $80 \%$. Dan ekstrak air

\begin{tabular}{ccc}
\hline \multirow{2}{*}{ Absorbansi (A) } & \multicolumn{2}{c}{ Konsentrasi $(\boldsymbol{\mu g} / \mathbf{m L})$} \\
\cline { 2 - 3 } & Ekstrak etanol 80\% & Ekstrak air \\
\hline 0,214 & 5,52 & 11,42 \\
0,223 & 6,13 & 11,85 \\
0,230 & 5,25 & 12,24 \\
0,244 & 5,48 & 12,93 \\
0,243 & 5,48 & 12,90 \\
\hline
\end{tabular}

Tabel 3. Perbandingan konsentrasi CAPE pada propolis ekstrak etanol dan propolis ekstrak air

\begin{tabular}{cc}
\hline Etanol $(\boldsymbol{\mu g} / \mathbf{m L})$ & Air $(\boldsymbol{\mu g} / \mathbf{m L})$ \\
\hline 11,42 & 5,52 \\
11,85 & 6,13 \\
12,24 & 5,25 \\
12,93 & 5,48 \\
12,90 & 5,48 \\
\hline
\end{tabular}

Tahapan berikutnya adalah uji varians data. Pada kotak Levene's test didapatkan nilai signifikansi $\mathrm{p}=0,125$. Oleh karena nilai $\mathrm{p}>0,05$ maka varians data pada kedua kelompok sama. Namun, varian data tersebut bukan merupakan syarat mutlak untuk dilakukan uji-t tidak berpasangan. Kemudian dilihat perbedaan rerata (mean difference). Perbedaan rerata menunjukkan hasil sebesar 6,704. Selanjutnya dilihat nilai $\mathrm{IK}=95 \%$. Nilai $\mathrm{IK}=95 \%$ berkisar antara 5,89441 dan 7,51359. Oleh karena nilai p>0,05 maka dapat disimpulkan tidak terdapat perbedaan rerata konsentrasi CAPE yang signifikan antara propolis ekstrak etanol dan propolis ekstrak air.

\section{Pembahasan}

Propolis adalah produk alami yang berasal dari resin tumbuhan yang dikumpulkan oleh lebah madu. Komposisi propolis terutama tergantung pada keberadaan tumbuhtumbuhan di daerah mana propolis dikumpulkan, waktu dikumpulkan, dan secara sekunder tergantung pada jenis pelarut yang digunakan untuk ekstraksi. Propolis tidak dapat digunakan sebagai bahan mentah dan harus dimurnikan melalui ekstraksi dengan menggunakan pelarut (Pietta et al. 2002). Cunha dalam Sforcin (2011) menyatakan bahwa ekstraksi menggunakan pelarut yang berbeda akan menghasilkan komponen yang berbeda serta mempengaruhi aktivitasnya. Kualitas ekstrak dipengaruhi oleh berbagai faktor, diantaranya bahan yang diekstrak, pelarut yang digunakan, dan prosedur ekstraksi.

Faktor-faktor yang mempengaruhi kuantitas ekstraksi di antaranya tipe ektraksi, waktu ektraksi, temperatur, pelarut alami, konsentrasi pelarut, serta polaritas. Dalam proses ekstraksi, pelarut berdifusi ke dalam material padat dan melarutkan komponen dengan polaritas yang sama (Prashant et al. 2011). Propolis biasanya diekstrak dengan menggunakan air atau etanol pada berbagai konsentrasi sebagai peralut (Park dan Ikegaki 1998).

Penelitian ini merupakan penelitian eksperimental yang bertujuan untuk mengetahui ada tidaknya perbedaan rerata kadar CAPE pada propolis ekstrak etanol dan propolis ekstrak air. Pada penelitian ini, faktor yang diteliti adalah jenis pelarut berupa etanol 80\% dan air. Etanol merupakan pelarut yang termasuk dalam golongan alkohol yang memiliki sifat mampu melarutkan lebih banyak polifenol jika dibandingkan dengan air, karena alkohol lebih efektif dalam mendegradasi dinding sel yang bersifat nonpolar, sehingga polifenol dapat lepas. Adapun air merupakan pelarut universal yang biasanya digunakan untuk mengekstraksi zat-zat yang memiliki aktivitas antimikroba. Pada pelarut air, terdapat enzim polifenol oksidase yang dapat menyebabkan polifenol terdegradasi. Enzim tersebut tidak aktif dalam etanol maupun metanol.

Hasil penelitian yang disajikan pada Tabel 3 menunjukkan bahwa konsentrasi CAPE pada propolis ekstrak etanol lebih tinggi daripada propolis ekstrak air. Hal ini sesuai dengan pernyataan Demestre et al. (2008) bahwa CAPE memiliki kelarutan yang rendah terhadap air.

Berdasarkan hasil analisis data penelitian menggunakan uji-t tidak berpasangan didapatkan $\mathrm{p}=0,125$ ( $\mathrm{p}>0,05)$. Hasil ini menunjukkan bahwa perbedaan rerata konsentrasi CAPE antara propolis ekstrak etanol dan propolis ekstrak air tidak signifikan.

Kelemahan dalam penelitian ini yaitu penelitian ini menggunakan metode ekstraksi maserasi sederhana yang berakibat pada sedikitnya bahan aktif yang terekstrak dari propolis. Selain itu, penelitian ini tidak menggunakan metode isolasi spesifik untuk mengisolasi CAPE.

\section{KESIMPULAN}

Terdapat perbedaan konsentrasi CAPE pada propolis ekstrak etanol dan propolis ekstrak air. Namun, perbedaan antara keduanya tidak signifikan.

\section{DAFTAR PUSTAKA}

Bankova V, Boudourova KG, Popov S et al. 1998. Seasonal variations of the chemical composition of Brazilian propolis. Apidologie 29: 361367.

Bankova V, Castro SL, Marcucci MC. 2000. Propolis: Recent advances in chemistry and plant origin. Apidologie 31: 3-15.

Banskota AH, Tezuka Y, Kadota S. 2001. Recent progress in pharmacological research of propolis. Phytother Res 15: 561-571.

Burdock GA. 1998. Review of the biological properties and toxicity of bee propolis (Propolis). Food Chem Toxicol 36: 347-363. 
Cicalaa C, Morelloa S, Iorioa C et al. 2003. Vascular effects of caffeic acid phenethyl ester (CAPE) on isolated rat thoracic aorta. Life Sci 73: 73-80.

Cottica SM, Sawaya ACHF, Eberlin MN et al. 2011. Antioxidant activity and composition of propolis obtained by different methods of extraction. J Braz Chem Soc 22: 927-933.

Dahlan MS. 2007. Statistika untuk kedokteran dan kesehatan: Deskriptif, bivariat, dan multivariat, dilengkapi "Aplikasi dengan menggunakan SPSS”. Seri 1. Salemba Medika, Jakarta.

Demestre M, Messerli SM, Celli N et al. 2008. CAPE (Caffeic Acid Phenethyl Ester)-based propolis extract (Bio 30) suppresses the growth of Human Neurofibromatosis (NF) tumor xenografts in mice. Phytother Res 23 (2): 226-230.

Frenkel K, Wei H, Bhimani R. 1993.Inhibition of tumor promotermediated processes in mouse skin and bovine lens by caffeic acid phenethyl ester. Cancer Res 53: 1255-1261.

Ghisalberti EL. 1979. Propolis: A review. Bee World, 60:59-80.

Gonzalez M, Guzman B, Rudyk R, Romano E, Molina MAA. 2003. Spectrophotometric determination of phenolic compounds in propolis.Lat Am J Pharm., 22 (3): 243-8.

Khayyal MT, el-Ghazaly MA, el-Khatib AS. 1993. Mechanisms involved in the anti-inflammatory effect of propolis extract. Drugs Exp Clin Res 9: 197-203.

Lotfy M. 2006. Biological activity of bee propolis in health and disease. Asian Pac J Cancer Prev 7: 22-31.

Marcucci MC. 1995. Propolis: Chemical composition, biological properties and therapeutic activity. Apidologie 26: 83-99.

Marquez N, Sancho R, Macho A, Calzado MA, Fiebich BL, Munoz E. 2004. Caffeic acid phenethyl ester inhibits T-cell activation by targeting both nuclear factor of activated T-cells and NF-kappa B transcription factors. J Pharmacol Exp Ther 308 (3): 993- 1001.

Mishima S, Yoshida C, Akino S, Sakamoto T. 2005. Antihypertensive effects of brazilian propolis: Identification of caffeoylquinic acids as constituents involved in the hypotension in spontaneously hypertensive rats. Biol Pharm Bull 28 (10) 1909-914.

Nagaoka T, Banskota AH, Tezuka Y, Midorikaka K, Matsushige K, Kadota S. 2003. Caffeic acid phenethyl ester (CAPE) analogues: Potent nitric oxide inhibitors from the Netherlands propolis. Biol Pharm Bull 26 (4): 487-491.

Najafi MF, Vahedy F, Seyyedin M, Jomehzadeh HR, Bozary K. 2007. Effect of the water extracts of propolis on stimulation and inhibition of different cells. Cytotechnology, 54: 49-56.

Ozen S, Akyol O, Iraz M, Sogut S, Ozugurlu F, Ozyurt H, Odaci E, Yildirim Z. 2004. Role of caffeic acid phenethyl ester, an active component of propolis, against cisplatin-induced nephrotoxicity in rats. J Appl Toxicol 24 (1): 27-35.

Park YK, Ikegaki M. 1998. Preparation water and ethanolic extract of propolis and evaluation of preparations. Bioschi Biotechnol Biochem 62 (11): 2230-2232.

Pietta PG, Gardana C, Pietta AM. 2002. Analytical methods for quality control of propolis. Fitoterapia 73 (1): 7-20.

Prashant T, Bimlesh K, mandeep K, Gupreet K, Harleen K. 2011. Phytochemical screening and ekstraction: A review. International Pharmaceutica Scinecia 1 (1): 98-106.

Rossi A, Longo R, Russoc A, Borrellia F, Sautebina L. 2002. The role of the phenethyl ester of caffeic acid (CAPE) in the inhibition of rat lung cyclooxygenase activity by propolis. Fitoterapia 73 (1): 30-37.

Sforcin J M, Bankova V. 2011. Propolis: Is there a potential for the development of new drugs?. J Ethnopharmacol 133: 253-60

Taufiqqurohman MA. 2009. Pengantar Metodologi Penelitian untuk Ilmu Kesehatan. Safei I., Hastuti S., Saddhono K. (eds). Surakarta: UNS Press, pp: 58, 101-2.

Widjaja A, Yeh T, Ju Y. 2008. Enzymatic synthesis of caffeic acid phenethyl ester. J Chinese Inst Chem Eng 39: 413-18. 